Georgia State University

ScholarWorks @ Georgia State University

\title{
Technological Innovation in China: The Case of Shanghai's Electronics Industry. Denis Fred Simon, Detlef Rehn
}

Penelope B. Prime

Georgia State University, pprime@gsu.edu

Follow this and additional works at: https://scholarworks.gsu.edu/intlbus_facpub

Part of the International Business Commons

\section{Recommended Citation}

Penelope B. Prime, "Technological Innovation in China: The Case of Shanghai's Electronics Industry. Denis Fred Simon, Detlef Rehn ,"Economic Development and Cultural Change 39, no. 3 (Apr., 1991): 673-678. DOI: 10.1086/451897.

This Review is brought to you for free and open access by the Institute of International Business at ScholarWorks @ Georgia State University. It has been accepted for inclusion in International Business Faculty Publications by an authorized administrator of ScholarWorks @ Georgia State University. For more information, please contact scholarworks@gsu.edu. 
more of Asia has proved, it is the realization of development that makes national cultures blossom. This book is proof that most Asians have moved beyond the psychological effects of colonialism and are at peace with their national traditions. It is only the old men of Beijing who strive to keep alive the nineteenth-century fears about foreign ideas with their repeated campaign against "spiritual pollution".seemingly forgetting that what they are striving to protect from outside influences is a foreign import, Marxism-Leninism.

Denis Fred Simon and Detlef Rehn. Technological Innovation in China: The Case of Shanghai's Electronics Industry. Cambridge, Mass.: Ballinger Publishing, 1988. Pp. xviii +206.

\section{Penelope B. Prime}

Carleton College

Technological innovation has been central to China's desire to modernize, especially since its leadership's decision to begin major economic reforms in the late 1970s. Technological Innovation in China, by Deris Fred Simon and Detlef Rehn, attempts to assess what impact China.s reform policies have had on technological change and innovation by examining the case of electronics in Shanghai. The book is an important contribution to our understanding of how the functioning of a centrally planned, bureaucratic economy affects the process of technological decision making. While many of the characteristics uncovered are similar to those in the Soviet Union and Eastern Europe, China's attempts to reform appear to be particularly astute in its leadership's frank recognition of the problems and the need for radical change.

One theme that clearly emerges in Simon and Rehn's study, however, is that changes in policy have been much more extensive than the actual implementation of those policies. The authors argue that this is largely because other supporting changes, especially reforms of the economic system, are needed before the stimulation of innovation will be successful. This theme is important considering that the case study of Shanghai is of the most technologically advanced area in China, especially in electronics. Shanghai also has been on the forefront of economic reform. Yet even in Shanghai the implementation of programs designed to stimulate technological change has yet to make much of a difference. The message is that China truly has a long way to go. Nonetheless, in the realm of intent, policies put forward in China over the past decade have been innovative and have recognized the severe obstacles of introducing dynamism in a bureaucratic, planned economy. This in itself is more than has been accomplished 
thus far in many other centrally planned economies and is worth studying for the potential it represents.

The book is organized into seven chapters. Chapter 1 is an overview of the process of innovation in planned economies and a comparison of China to the Soviet Union. The authors argue that in planned economies innovation is not generated by market forces but, instead, is part of the process of resource allocation by planners and government officials. It has long been hypothesized that centralized control over resources can support certain kinds of technological change, such as military hardware, but that this control comes into conflict with generalized innovation and its diffusion throughout the economy. One reason for this is that the forces shaping technological change from demand for new products or processes are weak, while key projects decided by government officials command the best resources and talent. Another reason is because research and development activities tend to be separated from production. The result is uneven technological performance with a few advanced areas of expertise amid generally low technological levels of both research and production. China's situation in these respects is no different than that of other planned economies, despite rejecting the Soviet "top-down" approach during the 1960s and 1970s.

Chapter 2 discusses China's efforts over the past decade to overcome these problems. It is interesting that China's first reaction was to return to the Soviet model of the $1950 \mathrm{~s}$ - that is, to improve the scientific and technological structure that already existed but had been rendered virtually lifeless as a result of the Cultural Revolution. This approach meant strengthening central control over resources and redirecting them toward areas where major technological change was considered to be crucial to the modernization effort-electronics being one.

It is not surprising that the problems that existed before, and still exist in other centrally planned economies, began to resurface with this centralized approach. China's response has been not to abandon this approach but to encourage entrepreneurial talent and develop market forces to complement the centrally directed approach. The authors refer to this as a "two pronged" strategy, unique among the planned economies, and suggest that it moves China more in the direction of countries like Taiwan, South Korea, and India. Although they recognize that such a strategy is not easily accomplished, they clearly hope that the positive features of a mix of market and state will overcome the inherent tensions in the Chinese case. In light of the evidence they themselves present throughout the book, these hopes seem overly optimistic.

Chapters 3 and 4 discuss the history of electronics development in China and the specific organization of that industry in Shanghai. 
These chapters establish the importance of Shanghai as a technologizal center in China and the role China's leaders have given to electronics over the years. The details of the organization of the electronics industry, and its strengths and weaknesses, help to elucidate the previous discussion of bureaucratic turf and overlap, the lack of links between research and production, and the desire of many of the actors to im. prove this situation radically.

Chapter 5 presents the main case study of the book-the semiconductor components industry in Shanghai. China developed its first integrated circuit in 1964, about 5 years later than the industrialized countries. Since then the gap has widened to about 10 years for research and development and to more than 15 years for the production of circuits with line widths smaller than 5-6 microns and densities larger than $1 \mathrm{~K}$ and $4 \mathrm{~K}$ (p. 117). Much of chapter 5 details the problems that have led China into this situation.

The authors discuss three settings in which innovation potentially takes place: domestic development of new products and processes, the absorption and linkages of imported technology, and Silicon Valley-type projects that combine both domestic and imported resources. In all three cases organizational problems and poor linkages betwe:en research and production, and between production and end users, have contributed to slow or unsuccessful innovation.

Domestic innovation in Shanghai's semiconductor industry is initiated by both central-level organizations located in Beijing and local government organizations, including actual work units within enterprises. In Beijing the organizations potentially involved include the State Council's leading group for the revitalization of the electronics industry, the State Science and Technology Commission, the National Defense Science and Technology Commission, the State Education Commission, the Chinese Academy of Sciences, and various industrial ministries. At the local level, the Economic Commission is responsible for new products, and the local Science and Technology Commission is responsible for new technology in the research and development sphere (p. 122). The Planning Commission is also involved in new projects, as are the local bureaus and their research units, of the appropriate industrial ministries. Exactly how, or if, these numerous organizations coordinate their activities is unclear. In any case, according, to the authors, after much time and effort the "new product or process is not often translated into production-primarily because the potential end users were never intimately involved in its design during the initial formulation of the project" (p. 124). In addition to the obstacles created by this vertical organization, organizational barriers exist within enterprises, and managers have disincentives to introduce new technologies. Further, there are weaknesses in the economic system, which reinforce these negative behaviors, such as little market influ- 
ence to stimulate or even transmit end user demand. These problems, of course, have been targets of the reform efforts, but this example underscores the size of the task.

Some leaders in China hope that foreign technology can act as a catalyst to help solve the problems in domestic research and production. The increase in joint ventures and trade with foreign companies has represented acquisition of significant quantities of technology, but the emphasis has clearly been on importing in order to improve domestic capabilities. These imports have made an impact on Shanghai's semiconductor industry as now most of the integrated circuits are copies of foreign models (p. 129). Problems of effectively utilizing these imports abound, however. Foreign projects cannot avoid dealing with much of the same bureaucracy as domestic projects and in some cases face even more obstacles. The authors report that one estimate of needed approval "chops" for a project in Shanghai was at least 126 (p. 130). And if a project is valued at over $\$ 5$ million, it must be directly reviewed by the central government (p. 133).

It is not surprising that the third approach-combining domestic and foreign resources in a Silicon Valley-type of arrangement-has so far remained in the planning and negotiation stages. Beijing approved the Caohejing zone in Shanghai but first changed its status from a local to a national level project. This may help with coordinating efforts, but it has also created friction with certain ministerial and local organizations. Of course, the whole concept is very different than that of Silicon Valley, because competitive forces are virtually nonexistent in the Chinese case. The authors' assessment of this experiment is that as an idea it is a step forward but that it currently lacks many critical elements needed to make it work.

So what innovative policies has China created to deal with these seemingly overwhelming problems? Aside from the reforms dealing with more generalized economic issues, chapter 6 discusses several specific reforms that have affected the electronics industry.

The recognition that technological change needs to be linked to end user demand has led to reforms creating a research contract system and technology markets. Previously, funding for research institutes within local government organizations came entirely from each organization's operating budget. Now research institutes must rely increasingly on consulting and technology transfer deals to support salaries and operating expenses. Pressure to become financially independent has been applied to civilian as well as to military-related research institutes, which has resulted in closer links between these two sectors. The establishment of technology markets in 1984 is closely related to the financial independence of research institutes, since technology is what they have to sell. These markets also necessitate links between researchers and producers-a key element missing in the old system. 
In Shanghai there are several channels through which these markets operate. Under the local Science and Technology Commission, the Shanghai Science and Technology Development and Exchange Center coordinates 34 corporations run by scientists and technicians and is involved with 17 technical development departments (p. 148). There is also the Shanghai Science and Technology Consulting and Service Center with 80 branches and five corporations, science and technology services provided by a number of universities and colleges, and technical institutions within local industrial bureaus. In addition there are collectively or individually owned companies, usually started by scientists in fields such as biotechnology and computer software. By 1937 there were about 160 of these companies in Shanghai, employing about 2,000 people (p. 155).

Another key aspect of the technology reforms are programs to modernize research and production equipment, facilities, and knowhow. The programs involve financing higher expenditures for research and development, acquisition of equipment and know-how from foreign or domestic sources, and dissemination of techniques to as many facilities as possible. The thrust is to improve existing facilities rather than construct entirely new ones. Aside from the up-grading of technology used in enterprises, these measures are designed to encoura;e managers interested in better production methods and to raise the payoff for engaging in experiments.

A third element of the reforms centers on the improvement of enterprise management, both in terms of management skills and in decision-making autonomy from government organizations. The desired outcome here is twofold. The first goal is to establish a horizontal, functionally oriented organization to replace the previous vertical lines of command that created inefficiencies, turf battles, and lack of cornmunication. The second goal is to establish proper incentives for managers and workers to care about the financial health of their enterprises and to take the necessary risks to develop and try new products and methods.

All three of these approaches are closely linked and mutually reinforcing. In order to affect technological change, however, they also require that the economic reforms be fully implemented. For example, technology markets or incentives for managers are not going to work unless sellers can properly price their products and be assured of receiving payments on their patents. With China's irrational price system and severe rigidities, these problems are far from minor.

The authors readily recognize these problems and end with a modest conclusion in chapter 7. They believe that Shanghai will establish itself as China's center for electronics and computer development and that electronics will be a leading sector in the economy (p. 173). While they found evidence of all the key elements needed for innovation in 
China, they also uncovered a lack of coordination and other serious obstructions to the innovative process. On the positive side, they were impressed with China's recognition of the problems and the sophistication of the discussion and content of reform measures. By the end of this study in 1987, however, only the beginnings of change were in evidence. Since then, a recentralization was begun in mid-1988, and the student movement was crushed in the spring of 1989. With the success of technological change so closely tied to economic change, and with the slowing if not retrenchment of economic reforms since these events, the authors' initial observation that "China appears embarked on its own version of a technological revolution" (p. Xv) would seem premature.

Robin Broad. Unequal Alliance: The World Bank, the International Monetary Fund, and the Philippines. Berkeley and Los Angeles: University of California Press, 1988. Pp. xxvii +352 . $\$ 35.00$.

\section{Richard Hooley}

\section{University of Pittsburgh}

This is an unusual book because it is not simply an assessment of the success of World Bank/IMF economic policies but deals rather with the attempts at political intervention from the early 1970s to the mid1980 s by these institutions in the design and implementation of macroeconomic policy in a borrowing country. It is based on the most extensive leak of Bank and Fund documents for any LDC through the solidarity network and recently published by W. Bello,' supplemented by interviews with about 100 political and business leaders. Though I have reservations about parts of the economic analysis as well as the author's interpretation of recent political events, the book does present a detailed, documented picture of Fund/Bank political intervention in an LDC, which is unique in the literature and probably unfamiliar to many economists.

Chapters 4-7 are the heart of the book and sketch out how the Bank and Fund operated behind the scenes to obtain implementation of the structural adjustment loans (SAL) designed to underwrite an export promotion strategy in the Philippines. The Bank and Fund gave their blessing (and full support) to a young generation of policymakers (technocrats) who were-in the Bank/Fund scenario-to be entrusted with implementing the policies of the new strategy-policies whose main contours were crafted in Washington. As the author correctly points out, the Bank and Fund then proceeded to interject themselves into domestic Philippine politics by virtue of their direct working rela- 
Copyright of Economic Development \& Cultural Change is the property of University of Chicago Press and its content may not be copied or emailed to multiple sites or posted to a listserv without the copyright holder's express written permission. However, users may print, download, or email articles for individual use. 